\title{
Landslide Disaster Risk Assessment Model in Soppeng Regency, South Sulawesi
}

\author{
Adi Maulana ${ }^{\text {a,b, } * \text {, Suharman Hamzah }}{ }^{\mathrm{c}}$, Iswandi Utama ${ }^{\mathrm{d}}$, Jamal Rauf Husain ${ }^{\mathrm{e}}$

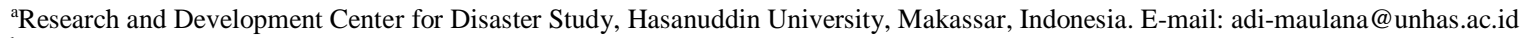 \\ ${ }^{b}$ Department of Geological Engineering, Faculty of Engineering, Hasanuddin University. \\ ${ }^{c}$ Department of Civil Engineering, Faculty of Engineering, Hasanuddin University, Indonesia. \\ ${ }^{\mathrm{d}}$ Department of Geological Engineering, Faculty of Engineering, Hasanuddin University. \\ ${ }^{e}$ Department of Geological Engineering, Faculty of Engineering, Hasanuddin University.
}

\begin{abstract}
Landslide disaster risk assessment model has been proposed for Soppeng Regency which is located in the central part of South Sulawesi Province. Some areas in this regency are classified as landslide prone area based on its geological condition. This study is aimed to assess the landslide vulnerability level and produce a landslide vulnerability map by using mapping method as a basis to model the risk reduction assessment. The component of disaster risk assessment consists of threats, vulnerabilities, and capacities. These components are used to obtain the level of disaster risk in an area by calculating the potential for exposed lives, loss of property and environmental damage. The result shows that Soppeng Regency region has some areas that are prone to landslides with low-high levels. The Vulnerability Assessment is classified as medium level whereas the result of landslide disaster capacity assessment is also shown as medium level. Bas ed on these analyses, it was concluded that Soppeng Regency had a high landslide threat index, with a medium exposed population index and a medium capacity index. The study of landslide disaster risk assessment in Soppeng Regency has shown that Soppeng Regency has been classified as landslide prone area with the medium risk level, especially in mountainous and river bank area. It is recommended that disaster risk assessment model should be used as one of the references for providing disaster risk mitigation plan in disaster risk reduction program.
\end{abstract}

Keywords: Assessment; disaster; landslide; risk; Soppeng; South Sulawesi

\section{Background}

Disaster risk assessment is the basis for choosing a strategy that is considered capable of reducing disaster risk. This disaster risk assessment must be able to become an adequate basis for regions to develop disaster management policies [1]. Disasters occur due to the collectivity of the hazard components that affect nature and environmental conditions, as well as how the level of vulnerability and capacity of a community in managing threats [2]. The higher the value of threats and vulnerability, the higher the risk of disaster to occur. To reduce the risk of disaster, the needs to reduce the value of vulnerability and increase the capacity of the community is of paramount importance that is by strengthening the capacity within the community to manage the environment, recognize the threat and know the impact that can be caused by the factors that cause the disaster [3].

*Corresponding author. Tel.: +62-821-9502-4779

Jalan Poros Malino km. 6, Bontomarannu, Gowa

South Sulawesi, Indonesia 90245
At the community level, the results of the assessment are expected to be a strong basis in planning disaster risk reduction efforts [4]. The value of disaster risk depends on the interaction between the magnitude of the threats and vulnerabilities. Hence, the interaction of threats, vulnerabilities, and external factors is the basis for conducting a disaster risk assessment of an area.

Soppeng Regency is one of the regencies in the province of South Sulawesi, Indonesia with the capital city located in Watansoppeng City. This regency has an area of about 1,500 $\mathrm{km}^{2}$ and can be divided into three geomorphological units, namely plain, hills and mountainous units. The plain unit occupies the eastern and northern sections with an area of $700 \mathrm{~km} 2$ with an elevation of approximately $60 \mathrm{~m}$ above sea level. Mountains and hills morphology has an area of about $800 \mathrm{~km} 2$ at an average altitude of $200 \mathrm{~m}$ above sea level. The plain unit is generally located in Walanae depression which is partially filled by material alluvial forming Lake Tempe in the north and the Walanae River, flowing to the east and southeast [5]. 
Judging from the existing morphological conditions, especially in mountainous morphology, some areas in this regency can be classified as landslide disaster area [6]. The landslide in this area has caused enormous damage in road construction, bridge, irrigation canal and settlement area [6]. In addition, BNPB in 2018 also included the Soppeng Regency, especially those in mountainous and hilly areas as landslide-prone areas. The landslide also accounts for less physical loss and human life [5]. As an effort to reduce disaster risk, a study on landslide disaster risk assessment in Soppeng Regency is conducted to reduce the level of vulnerability of landslides. The component of disaster risk assessment consists of threats, vulnerabilities, and capacities. This component is used to obtain the level of disaster risk in an area by calculating the potential for exposed lives, loss of property and environmental damage. In addition to reduce the level of risk, the study is also expected to be able to produce a landslide vulnerability map in Soppeng Regency. This vulnerability study report and map will be an adequate basis for the local government to develop disaster management policies. At the community level the results of the assessment are expected to be a strong basis in planning disaster risk reduction efforts.

\section{Regional Geology}

Soppeng Regency is included in Regional Geological Map of Pangkajene and Western Part of Watampone Map [7]. Almost $80 \%$ of Soppeng region is located in the Walanae Depression which was formed by a major north northwest - south southeast trending fault system of the Walanae Zone in Late Neogene. The Late Neogene basin is filled by clastic sediments containing fossils of Late Miocene age. The clastic deposit is called as Walanae Formation showing Late Miocene to Holocene clastic sequences. In the Soppeng area, the West Sengkang Basin sediments are dominated by calcareous grey clay $\neg$ stone in the lower part of the Walanae Formation, known as the Burecing Member, after Burecing Village along the Cabenge-Pampanua road. Locally, small carbonate reefs of the Tacipi Member were formed in the East Sengkang Basin, where these shallow marine facies interfingered with or conformably overlaid marine claystones representing the base of Late Miocene Walanae Forma $\neg$ tion. The claystone accumulated in the down faulted Walanae depression and north of the Bone Mountains [8]. The western part of the regency, especially in the mountainous hill, is covered by a series of very thick volcanic sequence called Soppeng Volcanic [7] which is Miocene in age. The volcanic consist of tuff, breccia and lava flow with the present of feldspathoidal rich volcanic rocks. The geological map of Soppeng Regency can be seen in Fig. 1 below.

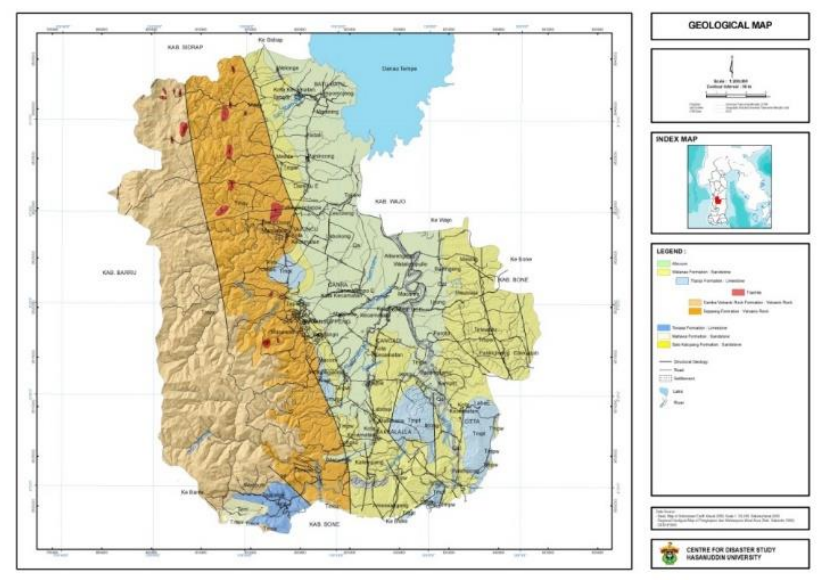

Figure 1. Geological map of Soppeng Regency [7]

\section{Methodology}

The method used in this study consists of 2 methods;

1) Mapping of landslide-prone areas in Soppeng Regency;

2) Risk reduction assessment method.

\subsection{Mapping disaster-prone}

General prerequisites for making a disaster-prone map are:

- Map scale with a scale of 1:50,000

- Able to count the number of people exposed to disasters.

- Able to calculate the value of property loss and environmental damage (in rupiah).

- Using 3 risk level interval classes, i.e. high, medium and low risk levels.

- Using GIS with Grid Analysis (10 meters) in disaster risk mapping.

\subsection{Risk reduction assessment method}

- Threat assessment method

Determination of the level of disaster threat using a threat level matrix, by combining the landslide hazard index in the lane with the population index exposed in the column. The threat index scale is divided into 3 categories: low (0.0-0.3), moderate (>0.3-0.6), and high (>0.6-1.0).

The exposed population index scale is divided into 3 categories, namely low, medium and high, with each index value as follows:

- Low: 0.0 - 0.3, if the population density is exposed to less than 500 people $/ \mathrm{Km}^{2}$, and the population of vulnerable groups is less than $20 \%$.

- Medium:> 0.3 - 0.6, if the population density is exposed to $500-1000$ people $/ \mathrm{Km}^{2}$, and the population of vulnerable groups is $20 \%-40 \%$.

- High:> 0.6 1.0, if the population density is exposed to more than 1000 people $/ \mathrm{Km}^{2}$, and the population of vulnerable groups is more than $40 \%$. 
- Vulnerability assessment method

Disaster vulnerability consists of socio-cultural, physical, economic and environmental components. Calculation of vulnerability of an area when exposed to a disaster threat consists of 3 vulnerability indices. The index is the Reported Population Index (in life units), Loss Index (in Rupiah units) and Environmental Damage Index (in hectares). Loss Levels can be prepared if the Threat Level in an area has been assessed. Loss Levels are obtained from combining Threat Level with Loss Indexes. Determination of Loss Levels is done using a matrix, determination is carried out by connecting the two index values in the matrix. The color of the meeting place symbolizes the level of loss that may be caused by a disaster in the area.

- Risk assessment method

Based on the identification of disasters described previously, the disaster index will be processed into a disaster risk assessment. In reviewing disaster risk studies, the guideline used is the General Guidelines for National Disaster Risk Assessment issued by BNPB in 2012. The guideline states that the disaster risk assessment will provide an overview of the regions related to the level of risk of a disaster in each region. Risk assessment consists of determining the level of threat, determining the level of loss and determining the level of capacity, especially in landslide disaster. This process is by reformulating the results of mapping and supplement maps in the form of a matrix into a predetermined value table. Figure 2 below illustrates the flow for the analysis of landslide disaster risk studies. From this figure, a level determination is made for each variable. Determination is made by connecting the two values described in accordance with the characteristics of the disaster.

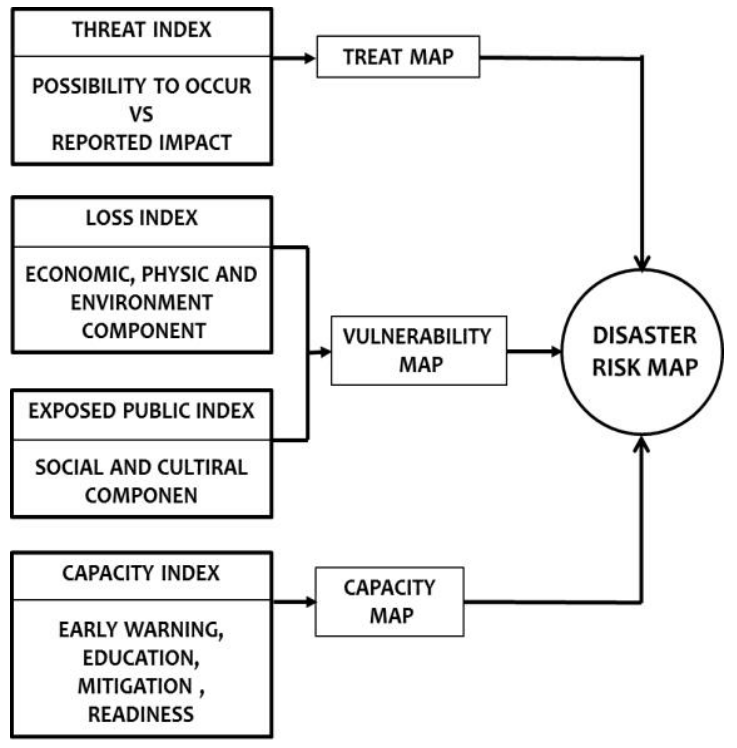

Figure 2. The flow diagram analysis of disaster risk studies [3]

\section{Results and Discussions}

Data processing in this study consist of several processes to obtain the parameters causing landslides. Rainfall, geology and land cover maps in the form of shapefiles are made of clips in the study area. Google earth image data processing is carried out by supervised classification which is classified into 10 classes of land cover namely Forests, Shrubs, Rivers, Gardens, Fields, Rice Fields, Open Land, Settlements, River Cliffs, Road Cliffs (Table 1). Then the results of the classification are tested with the field and IFSAR DEM processing is carried out to obtain the slope, the DEM is extracted into contours and slopes. The slope of the DEM is classified into 5 classes. The slope of the DEM data extraction is in the form of raster because it must be converted into shapefile data by reclassify to get the slope info table then convert raster to polygon. After the landslide parameters are obtained then a score is given for each class and the weights for each parameter are then overlaid. The processing flow is shown in Fig. 3 and Landslide vulnerability map can be shown in Fig. 4.

Figure 3. Flow diagram for Making Landslide Hazard Map Based on Soil
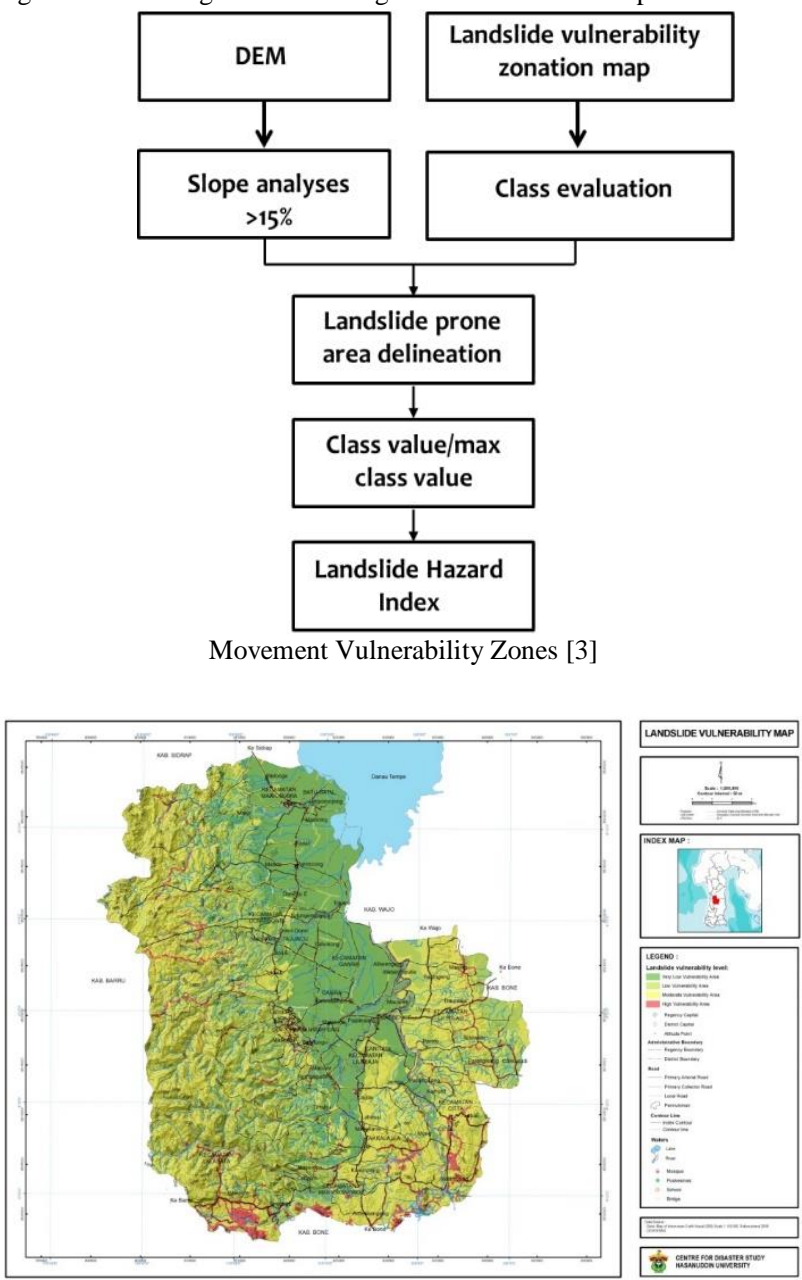

Figure 4. Landslide vulnerability map of Soppeng Regency 
Table 1. Parameters that affect the occurrence of landslides in Soppeng Regency

\begin{tabular}{|c|c|c|c|c|}
\hline Paramater & Unit & Score & Value & Percentage \\
\hline \multirow[t]{5}{*}{ Geology } & Alluvium & 3 & \multirow[t]{5}{*}{2} & \multirow[t]{5}{*}{$20 \%$} \\
\hline & Sandstone & 3 & & \\
\hline & Limestone & 4 & & \\
\hline & Volcanic Rock & 4 & & \\
\hline & Trakit & 1 & & \\
\hline \multirow[t]{4}{*}{ Slope } & $>40 \%$ & 3 & \multirow[t]{4}{*}{3} & \multirow[t]{4}{*}{$30 \%$} \\
\hline & $25-40 \%$ & 2 & & \\
\hline & $15-25 \%$ & 2 & & \\
\hline & $0-15 \%$ & 1 & & \\
\hline \multirow[t]{2}{*}{ Rain fall } & $2000-2500 \mathrm{~mm}$ & 2 & \multirow[t]{2}{*}{1} & \multirow[t]{2}{*}{$10 \%$} \\
\hline & $1500-2000 \mathrm{~mm}$ & 1 & & \\
\hline \multirow[t]{8}{*}{ Land Cover } & Forest & 1 & \multirow[t]{8}{*}{3} & \multirow[t]{8}{*}{$30 \%$} \\
\hline & Bush & 1 & & \\
\hline & Garden & 1 & & \\
\hline & Field & 1 & & \\
\hline & Open land & 2 & & \\
\hline & Settlement & 2 & & \\
\hline & River Bank & 3 & & \\
\hline & Road cliff & 3 & & \\
\hline \multirow{5}{*}{$\begin{array}{l}\text { Soil } \\
\text { Weathering } \\
\text { rate }\end{array}$} & Soil thickness & 3 & \multirow[t]{5}{*}{1} & \multirow[t]{5}{*}{$10 \%$} \\
\hline & $>1 \mathrm{~m}$ & & & \\
\hline & Soil thickness & 2 & & \\
\hline & $0.3-1 \mathrm{~m}$ & & & \\
\hline & $\begin{array}{l}\text { Soil thickness } \\
<0.3 \mathrm{~m}\end{array}$ & 1 & & \\
\hline
\end{tabular}

Determination of the level of vulnerability of the landslide area in the study area is based on the estimation model of the landslide-prone area by being adjusted to the parameter conditions that triggered the landslide in Soppeng Regency using the following formula:

Score $=(10 \% \times$ rainfall class factor $)+(20 \% \times$ geology $)+$ $(10 \% \times$ weathering class factor $)+(30 \% \times$ land use $)+$ (30\% x slope class factor)

\subsection{Disaster threats assessment}

Soppeng Regency region has some areas that are prone to landslides with low-high levels. The threat of landslides with high levels of landslides is in the southern part of Soppeng Regency, especially along Walanae River bank and several in the western part of Soppeng Regency. River bank landslides are the impact of high destructive power water flow during heavy rain which eroding river bank and river bed. Walanae River in Soppeng Regency is one of the locations that are affected and have river bank landslide vulnerability. The occurrence and vulnerability of river bank landslides can be analyzed through river morphometry and land use. The tendency of river morphometry to affect river bank landslide vulnerability can be analyzed through river bank landslide vulnerability maps which are validated by field checks.
Slopes from road sections are very susceptible to landslides, especially road slopes in the form of settlements and vacant land. Factors that cause landslides are caused by road cuts that are too steep, absence of talud on the road slopes, cuts in drainage and slopes left unused. Lithology of rocks on the slopes of the road which is volcanic rock is very vulnerable because the clay material from tuff is very easy to weathered and erode hence cause the path of water seepage that can be a trigger for landslides.

\subsection{Landslide vulnerability assessment}

Around 73 percent or 109,000 hectares of Soppeng Regency are in hilly areas with a slope of between $25-45 \%$ $\left(10-23^{\circ}\right)$ and more than $45 \%\left(>23^{\circ}\right)$. Technically, this area is very prone to landslides especially along the road slopes and settlements in hilly areas and triggering the mass movement. The mass movement can occur if rainfall is above normal, especially in areas bordering river valleys, cliffs, road cliffs or if slopes are disturbed.

Based on the Vulnerability Assessment, a landslide disaster in Soppeng Regency will affect 37,570 people who live and/or have activities in areas prone to landslides. For the Index of Losses, the results of the disaster risk assessment show that physical losses amounted to Rp.114,315,000,000 and economy due to landslide disasters amounting to Rp. 97,124,562,144. The threat of landslides also has the potential to damage the environment. The Environmental Damage Index due to landslides from a broad disaster risk assessment and threatened threat index is calculated around 2,698 Ha. The vulnerability factors of the landslide are mainly due to changes in land use to settlements, agriculture and plantations, roads, population density, and community behavior. Areas that were once forests then shifted into other functions, causing the area to be prone to landslides. Table 2 below shows the Soppeng Regency in various levels of landslide hazards.

\subsection{Landslide disaster capacity assessment}

Capacity for landslides covers various things such as facilities and infrastructure, information systems, human resources and community preparedness. The local government has been and is making various efforts to prevent landslides including construction such as gabions on slopes that have been opened for the benefit of building public facilities such as roads and settlements. The result of landslide disaster capacity assessment is shown in Table 3. For early information on landslides in Soppeng Regency, the following matters are needed to be considered;

- The existence of cracks in the land (agriculture, forest, gardens, and settlement) and/or roads that tend to get bigger in volume that can easily be seen visually.

- There are markings / subsidence on the asphalt road that can be seen visually. 
- Installation of rainfall meter around areas prone to landslides. If the cumulative rainfall in a row for 2 days exceeds $200 \mathrm{~mm}$ while the $3^{\text {rd }}$ day still seems to be raining, the community must be vigilant.

- The presence of water seepage at the foot of the slope, road cliffs, house yard cliffs (previously there has never been a renovation) or the flow of seepage (discharge) is greater than before.

- The existence of trees whose position is leaning towards the bottom of the hill.

- Changes in land cover (from forest to non-forest) on steep sloping land and moderate depth of soil.

- The existence of cliff cuts for roads and or housing on steep sloped land and deep soil layers.

\subsection{Landslide risk assessment}

Soppeng Regency has a high risk of landslides, especially on the slopes of road and river bank. The records of landslide events in Soppeng Regency both in terms of frequency and scale clearly show this threat is increasing. Figure 4 is a map of landslide-prone hazards in Soppeng Regency. Based on the study of disaster risk, it was concluded that Soppeng Regency had a HIGH landslide threat index, with a MEDIUM exposed population index and a MEDIUM capacity index (Table う).

Table 2. Loss Level due to disaster in Soppeng Regency South Sulawesi Province

\begin{tabular}{|c|c|c|c|c|}
\hline \multicolumn{2}{|c|}{ LOSS LEVEL } & \multicolumn{3}{c|}{ LOSS INDEX (IN RP) } \\
\cline { 3 - 5 } & LOW & MEDIUM & HIGH \\
\hline \multirow{2}{*}{$\begin{array}{c}\text { HAZARD } \\
\text { INDEX }\end{array}$} & LOW & & & \\
\cline { 2 - 5 } & MEDIUM & & & \\
\cline { 2 - 5 } & HIGH & & Landslide & \\
\hline
\end{tabular}

Table 3. Capacity level of Soppeng Regency South Sulawesi Province

\begin{tabular}{|c|c|c|c|c|}
\hline \multicolumn{2}{|c|}{ CAPACITY LEVEL } & \multicolumn{3}{|c|}{ CAPACITY INDEX } \\
\cline { 3 - 5 } & LOW & MEDIUM & HIGH \\
\hline \multirow{2}{*}{ HAZARD } & LOW & & & \\
\cline { 2 - 5 } INDEX & MEDIUM & & & \\
\cline { 2 - 5 } & HIGH & & Landslide & \\
\hline
\end{tabular}

Table 4. Landslide Risk Disaster Level of Soppeng Regency South Sulawesi Province

\begin{tabular}{|c|c|c|c|c|}
\hline \multicolumn{2}{|c|}{ DISASTER THREAT } & \multicolumn{3}{|c|}{ CAPACITY INDEX } \\
\cline { 2 - 5 } \multicolumn{2}{|c|}{ LEVEL } & LOW & MEDIUM & HIGH \\
\hline \multirow{2}{*}{ HAZARD } & LOW & & & \\
\cline { 2 - 5 } INDEX & MEDIUM & & & \\
\cline { 2 - 5 } & HIGH & & Landslide & \\
\hline
\end{tabular}

\section{Conclusions}

The study of landslide disaster risk assessment in Soppeng Regency has shown that Soppeng Regency has been classified as landslide prone area with the medium risk level. The landslide disaster risk assessment method can be used as a reference to provide disaster risk mitigation plan which is very important to reduce the risk of the disaster.

\section{Acknowledgments}

The study is supported by Penelitian Riset Unggulan Universitas Hasanuddin (RUNHAS) 2019 scheme. The authors express their thanks to the Head of BPBD Soppeng for data support.

\section{References}

[1] Klinke, A., Renn, O., A new approach to risk evaluation and management: risk-based, precaution-based, and discourse-based strategies. Risk Analysis 22(6), 1071-1094, 2002.

[2] The Royal Society, Risk analysis, perception and management', UNISDR, 1992.

[3] BNPB, General Guidelines for National Disaster Risk Assessment. Jakarta, Indonesia, 2012.

[4] Djalante, R., Disaster risk reduction and climate change adaptation in Indonesia: Institutional challenges and opportunities for integration International Journal of Disaster Resilience in the Built Environment 3(2), 166-180, 2012.

[5] BPBD Soppeng, Disaster Information Data of Soppeng Regency. Soppeng, Indonesia, 2018. [in Bahasa]

[6] Maulana, A., Geological constraints for disaster mitigation model in South Sulawesi. Journal of Physic, IOP Conference Proceeding Series, 2019.

[7] Sukamto, R., Geological Map of Pangkajene and Western Part of Watampone, Geological Research Centre, Bandung, Indonesia, 1982.

[8] Suyono., Kusnama, Stratigraphy and Tectonics of the Sengkang Basin, South Sulawesi. Jurnal Geologi Indonesia, 5, 1-11, 2010. 